\title{
PHYSICAL ELEMENTS OF ACCESSIBILITY FOR WAYFINDING IN AN INFORMATION DEFICIT TOURISM AREA
}

\author{
Isabella Nindya Laksita1, Syam Rachma Marcillia' ${ }^{2 *}$ \\ Department of Architecture and Planning, Universitas Gadjah Mada, Indonesia ${ }^{1}$ \\ Department of Architecture and Planning, Universitas Gadjah Mada, Indonesia ${ }^{2}$ \\ e-mail: ${ }^{1}$ isabella.n.laksita@gmail.com, ${ }^{* 2}$ syam.r.m@ugm.ac.id
}

\begin{abstract}
Abstrak_ Riset ini menyelidiki desa Sanggrahan sebagai pemukiman padat dan perkembangan organik yang sudah tumbuh dari waktu ke waktu menjadi pusat industri rumah tangga bakpia, sebagai tujuan wisata kuliner yang penting di Yogyakarta. Tujuan dari riset ini yaitu untuk menyelidiki pengaruh unsur-unsur fisik aksesibilitas sebagai strategi pencarian arah turis di wilayah defisit data untuk keberlanjutan kawasan pariwisata. Metode riset ini merupakan pemetaan kognitif dan kuesioner terbuka. Hasilnya menunjukkan bahwa di wilayah defisit data, turis cenderung melewati jalan dengan konektivitas yang lebih baik dari semula. Minimnya data di desa, memungkinkan turis menggunakan elemen fisik kota untuk mencari informasi aksesibilitas seperti jalan, simpul, tepi, dan landmark sebagai panduan untuk mencari jalan mencapai toko bakpia, meskipun kondisi fisik elemen dari aksesibilitas ini tidak memadai. Sebaliknya, konsep distrik digunakan oleh turis untuk mengetahui posisi mereka di distrik penjualan Bakpia Pathuk.
\end{abstract}

Kata kunci: Elemen Fisik; Mencari Jalan; Desa Sanggrahan.

\begin{abstract}
This study investigates Sanggrahan village as a dense and organic growth settlement that has developed over time into a center of bakpia-making home-industry, a crucial culinary tourism destination in Yogyakarta. The purpose of this research is to investigate the influence of physical elements of Accessibility to the touristswayfinding strategy in an information deficit area for the sustainability of the tourism area. The method of the study is cognitive mapping and open-ended questionnaires. The results show that in the information deficit area, tourists tend to go through paths with more excellent connectivity from their origins. In the village, the lack of information allows tourists to utilize the physical elements of the city for accessibility information such as paths, nodes, edges, and landmarks as guidance for wayfinding to reach the bakpia shops, even though these physical elements of accessibility conditions are inadequate. In contrast, the concept of the district is used by tourists to know their position in the Bakpia Pathuk sales district.
\end{abstract}

Keywords: Physical Elements; Wayfinding; Sanggrahan Village.

\footnotetext{
${ }^{1}$ Department of Architecture and Planning, Universitas Gadjah Mada, Indonesia

2 Department of Architecture and Planning, Universitas Gadjah Mada, Indonesia
} 


\section{INTRODUCTION}

Besides attraction and amenities, Accessibility is one of the three essential aspects of tourism. Sunaryo (2013) states that the Accessibility of tourism is a whole facility that provides convenience to tourists to reach a destination or related tourist destinations. This aspect is specifically important in a tourism area because good Accessibility enables visitors to participate in enjoyable and memorable tourism experiences that will increase the return rate to tourism attraction.

The physical elements of Accessibility are essential for the tourists' wayfinding to ensure they can easily access tourist destinations, products, and services. Lynch (1985) mentions the importance of wayfinding is to facilitate visitors to gain knowledge about situations that will enrich the quality of their experience, while Zomer et al (2019) stated that wayfinding is necessary it is to explain the conduct of route selection, identify potential navigational issues, design more accessible cities, and provide comprehensible travel information. Differences in travel behavior are supposed to determine the extent to which it is necessary for individuals to find ways and navigational preferences.

Several types of research explored travel behavior in association with visitors' wayfinding habits and more typical everyday travel features, primarily by asking for the frequency of visits to specific communities or locations as explained by Turano et al. (2009); Piccardi, Risetti, dan \& Nori (2011); Phillips (2013); Cashdan et al (2016). While visitors' travel activity relates to the physical settings at route level is typically analyzed in the form of a summary of the variations in size, turns, or most crossed intersections between chosen alternatives. Kuliga et al. (2019); Furman et al. 2014). Some physical factors in wayfinding that affect the visitors arrive at a destination originate from spatial arrangements (signage and directions) and maps obtained(Passini 1984). While Kuilga (2019) added that the configuration of space and visual Accessibility between locations are the main factors that affect on the difficulties in identifying routes within a building.

Kikon and Karlsson (2019) state that wayfinding analyses highlight the primary use of physical characteristics such as large buildings, vibrant façades, recognizable entrances/exits, staircases, halls, columns, and sculptures. These often act as markers in the built environment for navigation and orientation. (Vanderberg, 2016). El Ali, Bachour, Heuten, and Boll (2016, p. 10) Note that for the task of finding an unfamiliar point of interest, "people draw on multifaceted strategies but also importantly seeking out the nearest well-known landmark." It underlines the value of planning the built environment's physical features with a view to wayfinding (Maina \& Umar,2015).

Downs and Stea (1973) states that humans can simulate wayfinding mentally. The formation of a decision plan can be formed by a mental-path simulation (cognitive mapping); this process can be seen as a way to evaluate the feasibility of the project. The cognitive map is a visual representation of one's psychological state of the environment. This requires experience to build cognitive maps, as this is an accumulation and record of collective expertise in the background. In other words, one's constructive knowledge of a familiar environment (Kaplan and Kaplan 1982). Chia and Holt, (2009) and Tsoukas (2010) note that understanding the primacy of purposeful action and professional, realistic coping helps us to provide an alternative account of the development of the cognitive map without resorting to the language of purposeful objectives, goals, expectations and pre-thought techniques or even the style of systems and common logic.

While the wayfinding is about effective communication as a system, according to Apelt, Crawford, and J. Hogan (2018), it relies on a sequence of contact cues generated by our sensory 
system of visual, auditory, tactile and olfactory elements: architectural, graphic, audible and physical communication. They also note that any optical wayfinding device is more than just a sign - it involves the design, landscape architecture, light, and landmarks, as well as points of orientation.

Wayfinding mechanisms are evaluated by how people view an environment and how to interface components make it easier to get from point A to point B. Wayfinding systems should reassure users, create a pleasant and comfortable atmosphere, and hopefully have responses to future questions before users need to seek assistance. Wayfinding systems can also tell where users are not allowed to go.

This paper study Village Sanggrahan Pathuk Yogyakarta, as one of the bakpia-making homeindustry centers, which has become a tourist destination based on the decision of Municipality Government of Yogyakarta. In the past, Village Sanggrahan is a residential settlement located in urban areas. Over time, private houses in the village organically grew into not only as a place of production but also as a place to sell bakpia and now is widely known as bakpia culinary tourism center. However, Village Sanggrahan is unique as a tourist attraction because they have grown not by design but organically grown over time. A thorough observation showed that the spread of Bakpia Producers (as an attraction) in Village Sanggrahan and the condition of physical elements inside the village become the determinant points of tourist wayfinding. This study focuses on how the tourists of Village Sanggrahan do their wayfinding with physical aspects of Accessibility in a deficit information area.

The results show that in the information deficit area, tourists tend to go through paths with more excellent connectivity from their origins. In the village, the lack of information allows tourists to utilize the physical elements of Accessibility such as paths, nodes, edges, and landmarks as guidance for wayfinding to reach the bakpia shops, even though these physical elements of accessibility conditions are inadequate whereas the concept of the district is used by tourists to know their position in the Bakpia Pathuk sales district.

\section{METHOD}

This study uses cognitive mapping technique and open-ended questionnaire conducted in Village Sanggrahan Pathuk, Ngadiwinatan Village, Ngampilan District, Yogyakarta (Figure 1). With Slovin formula calculation, the study acquired 50 respondents. The respondents are determined by purposive random sampling method with criteria namely first-timer or repeater tourists; coming alone, in couple, or in groups; and without a guide. The boundaries of Village Sanggrahan Pathuk, are as follows:

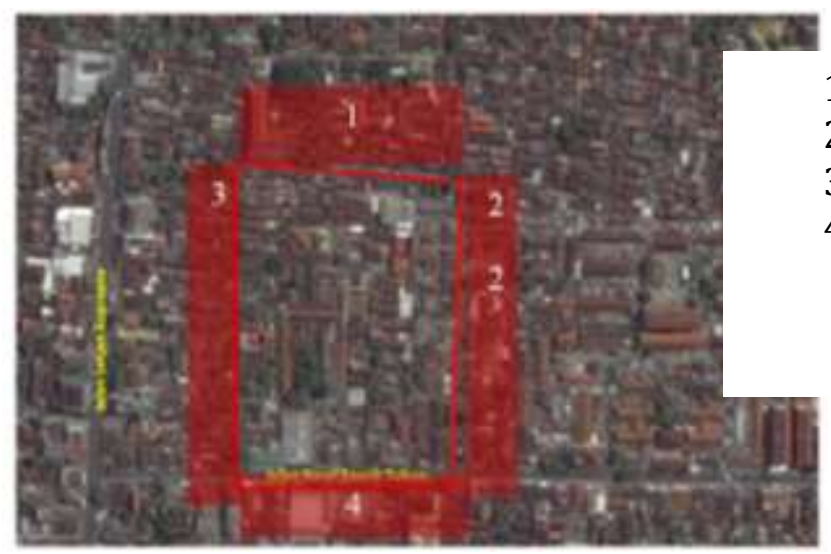

1. north : Gedong Tengen Ditch

2. east : RW 06 (Polri Complex)

3. south : Karel Sasuit Tubun Street

4. west : RW 04 (near Ilham Mosque)

Figure 1. Location of Kampung Sanggrahan Source: Author, 2017 


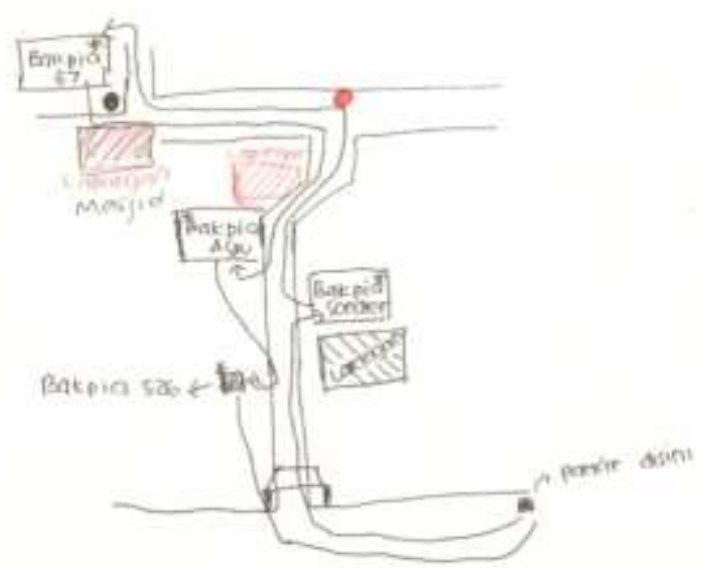

Figure 2. Sample of Respondents' Sketch Map Source: Author, 2017

In the research, the respondents were handed out questionnaires that asked them to evaluate their tourism experiences and the accessibility condition for wayfinding. They were also asked to draw a sketch map (cognitive mapping example in figure 2) of their wayfinding experiences and writing down the essential physical elements of the Accessibility that become valuable information for their wayfinding include landmark, path, node, edge, and districts.

In the analysis phase, evaluation, verification, and synthesis were conducted as follows:

1. Mapping analysis of the spread of bakpia producers in Village Sanggrahan, i.e. by tracing the map of the area from Google Earth, and adjusting it with the results of observation, interview and documentation.

2. Analysis of respondent's profile and route to the location related to tourist cognition using cognitive map and questionnaire. Questionnaire distribution points are based on categories such as regional streets, namely linear, winding, and joint.

3. Analysis of physical elements of Accessibility as determinants for tourist wayfinding that was conducted by analyzing the results of the questionnaire answers

\section{RESULT AND DISCUSSION}

\section{A. Respondents' Profile}

From a total of 50 respondents, the data of $58 \%$ female and $42 \%$ male were obtained. Respondents are categorized by age group, and it is known that most of them are 25-34 years old (52\%), which is the productive age group according to the Central Bureau of Statistics. Respondent categories based on the main types of occupations are divided into several categories. Most of them are entrepreneurs (30\%), employees (26\%), housewives (16\%), government employees (10\%), students (10\%), and there were also pensioners (2\%).

Tourists who come to Village Sanggrahan and bakpia shops are mostly first-timer. The starting points of the tourists before heading to Village Sanggrahan were home or hotel (50\%), other tourist attractions (46\%), and transit areas such as airport, station, and terminal (4\%). Based on the number of respondents' accompaniments, they were divided into the ones who came alone (8\%), those who came with family (28\%), and those in groups (36\%). As for the purpose of coming to this village, $54 \%$ of them were to buy bakpia and others, while $46 \%$ of others were to buy the only bakpia.

Most of the respondents got information about the village from the internet (30\%), family (20\%), friends (18\%), and others (16\%). Information from the internet includes a map 
of the location and how to get to the village, but the availability of information within the village is still lacking. 14\% of respondents found out about this village because they happened to be around the location of this place, while $2 \%$ of others knew this place from the tour guide, but they were not guided directly to the site. Respondents who came mostly consulted the map first before coming to this area.

The majority of respondents came from Provinces of Central Java (42\%), East Java (22\%), and Special Capital Region of Jakarta (12\%). Most of the respondents who came to Village Sanggrahan came from areas in Java province because geographically, Central Java Province, East Java Province, and Special Capital Region of Province have a relatively close distance with the Province of Special Region of Yogyakarta, compared to other regions.

Modes (Types) of transportation used by the respondents mostly were the private mode of transportation (private transport) (50\%), rented mode of transportation (rented transportation) (38\%), public transportation (10\%), and other (2\%). This is because respondents coming from areas in Central Java Province prefer to go with private transportation because the distance is relatively closer.

\section{B. The Importance of Paths Connectivity for Wayfinding}

Based on the cognitive map, pathways and connectivity is the most important thing to get to village. From Figure 3 it is known that the main access to Village Sanggrahan is the local street (K.S. Tubun Street) as a connecting street to other areas connected by secondary collector street (Letjend Soeprapto Street and Bhayangkara Street) so that all respondents illustrated Jalan KS Tubun (R2) on the route map. Figure 3 below explains the width of the road and the percentage of respondents using the way.

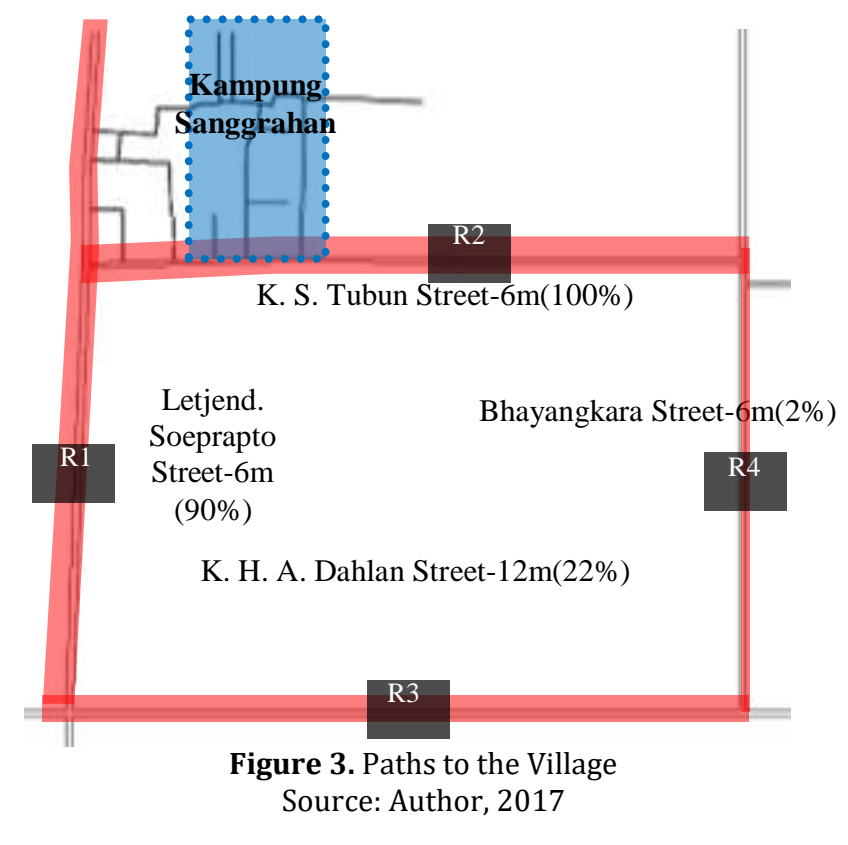

The physical elements around the village, such as gates, signages, and buildings, are also essential parts of tourist wayfinding strategies.

In Figure 4 explains the percentage of respondents who remember the physical elements around village, Figure 4 shows that main gates are used by the respondents as markers on the route to Village Sanggrahan. Gate of Bakpia Pathuk Industrial Center of (G1) 
and Village Sanggrahan Gate (G2) are included as identification signs (Passini, 1984), as markers that identify objects, places or people in space.

Buildings B1, B2, B4 and B5 are also used by the respondents as markers to Village Sanggrahan, as they are located at the opposite side of village entrance (Figure 4). Respondents tend to remember the buildings that are close to village entrance as a marker to find the location of the village.

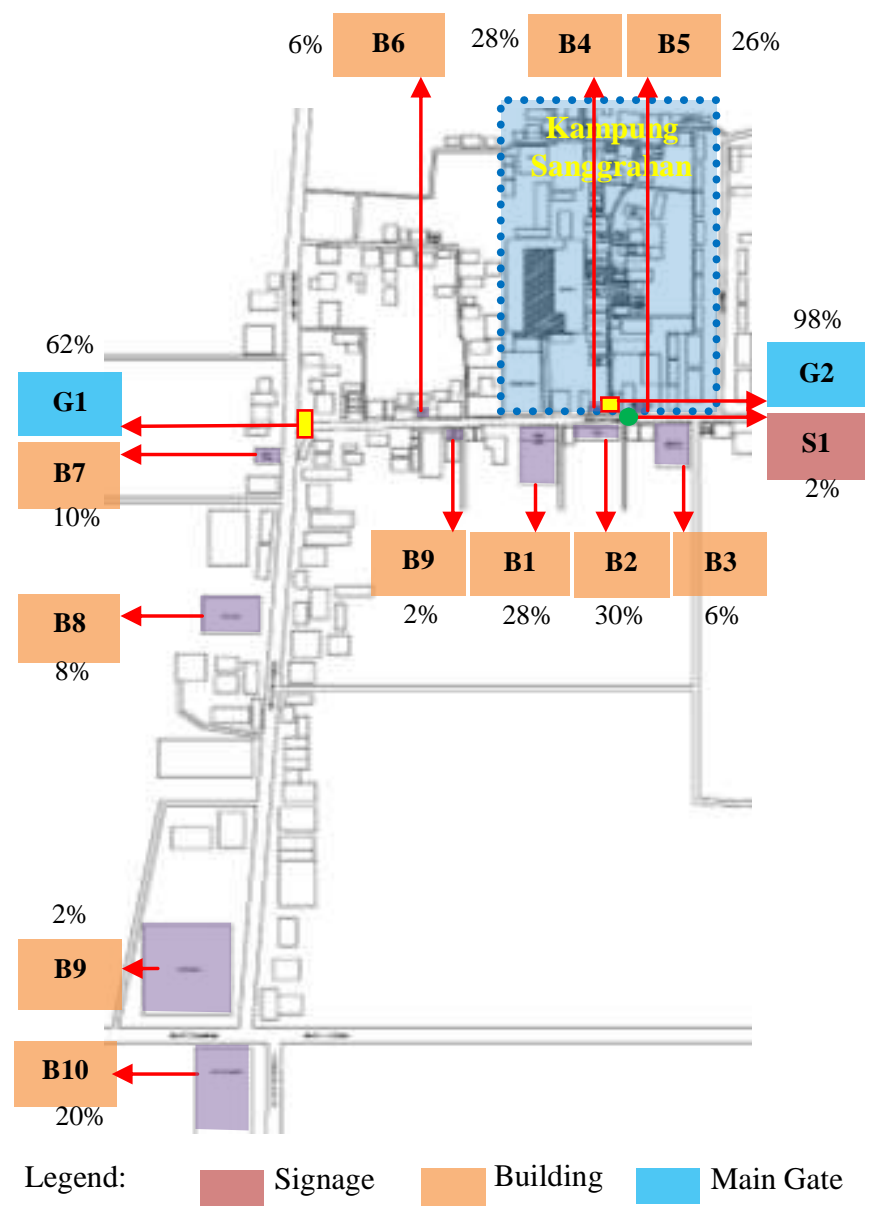

Figure4. Respondents' Cognitive Map to Village Source: Author, 2017

\section{Physical Elements of Accessibility in an Information Deficit Area}

As a tourism destination, Village Sanggrahan lacks information, both information on how to get to the village, and on within the village itself. Figure 5 shows the entrance road and the usage percentage of the entrance by the tourist. From the picture, it is known that the access within Village Sanggrahan is distinguished by the type of street configuration, i.e., linear, winding, and joint(Ching 2014). The main street of the village (R6) can be accessed by bicycle, motorbike, pedicab, and walking, while R8 and R9 can be accessed by four-wheeled vehicles. Respondents tend to go through streets marked with entrance gate (R6), although it is not accessible by four-wheeled vehicles.

First-timers tend to remember bakpia shops that are on the main street of the village with a linear configuration because it is easier to remember. First-timers also tend to do more exploration in the village than repeaters, while repeaters tend to visit bakpia shops that have been visited before. 


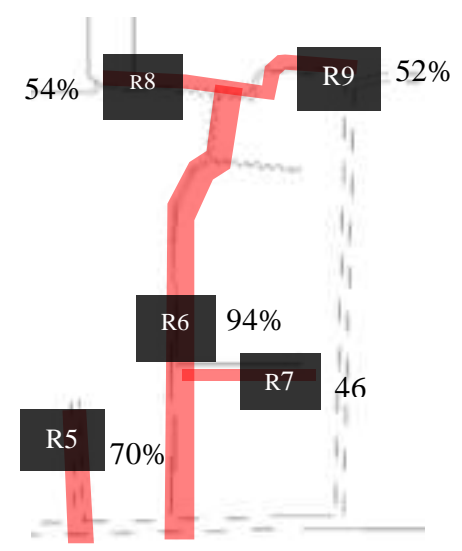

Figure 5. Paths within the Village Source: Author, 2017

Figure 6 shows the percentage of tourists in remembering physical elements such as gates, dividing walls, and open spaces, for wayfinding inside the village. In figure 6, public spaces are also retained by respondents on their route because (L1 and L3) are large and are located close to the entrance. Dividing walls with a mural (D1) form a corridor and are found after the village's main entrance. These dividing walls have the potential to develop the village character because they can create a preliminary impression for tourists when they enter the village area. Meanwhile, the village gate (G2) is also remembered by the respondents because it is also located near the village main entrance.
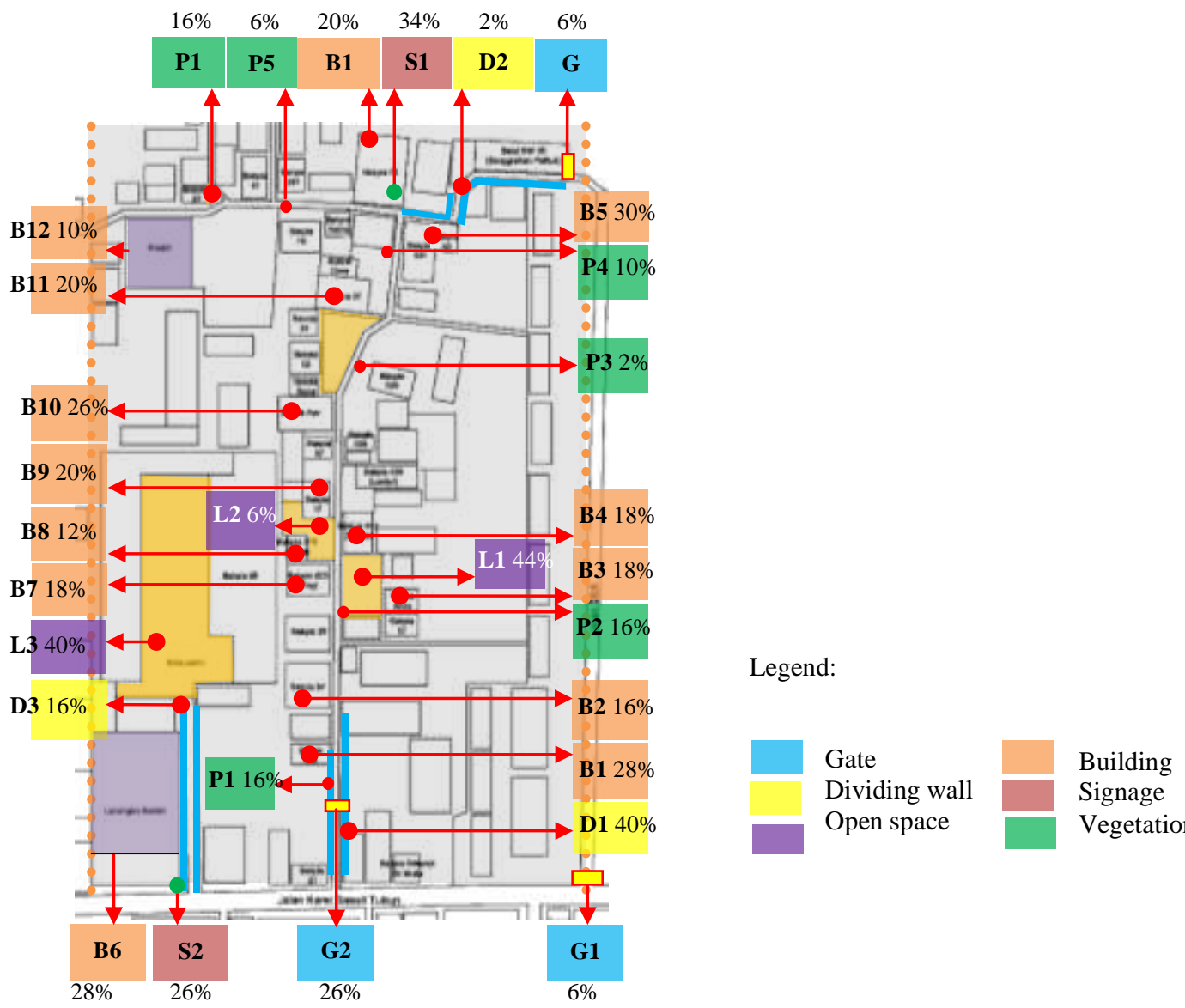

Figure 6. Respondents' Cognitive Map within the Village Source: Author, 2017 
The buildings within the village that are used as markers by the respondents are buildings located close to the entrance (B1 and B5), open areas (B2, B3, B8, B9, B10, and B11), crossroad (B4 and B13) and large (B6). Buildings that are close to the entrance and the first building tend to be more remembered by the respondents. Medium-sized buildings (B8) that are close to open areas less recognized by the tourists. (Figure 6)

The directional board in the village is inadequate. Direction board (S1) is remembered by respondents because it is located in the crossroad within the village, while (S2) is located near the main street (K.S. Tubun Street). Most of the signboards in the village are the signboards of bakpia shops. Every shop owner makes their signboard as a guide to find the shop, and there is no arrangement for the signs within the village. (Figure 6).

Respondents tend to remember the vegetation (P1) located at a crossroad and close to the west boundary of Village Sanggrahan. This vegetation is also equipped with a board containing information on the Sanggrahan Village boundary. (Figure 6)

Figure 7 provides a summary of the mean number of respondents cognitive map features for the 50 cognitive maps acquired. The highest mean number of elements was for open spaces and signages (mean $=15$ public spaces per plan), dividing walls were also dominant features of the maps (mean=9,66 dividing walls per policy). Although open spaces and signages within the village are inadequate, they remembered by respondents as guidance.

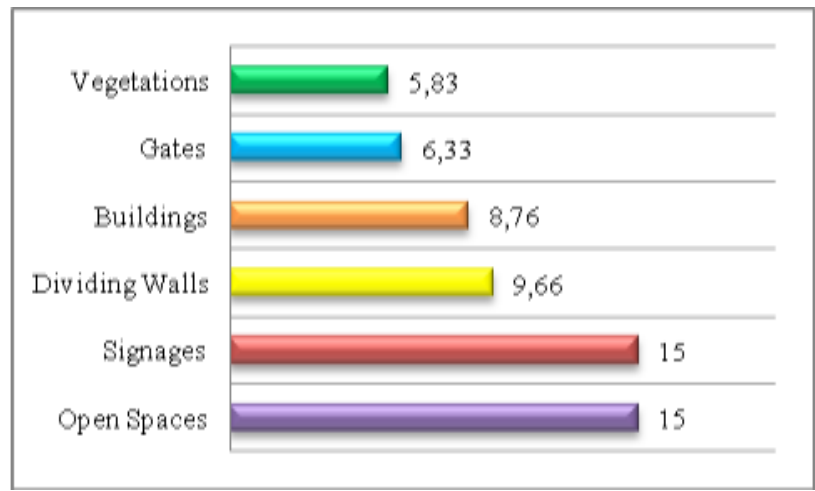

Figure 7. Summary of Means for Respondents' Cognituve Maps Feature) Source: Author, 2017

\section{The connection between Accessibility as a Determinant Physical Elements of Tourist Wayfinding}

Accessibility in the wayfinding process also includes the availability of information. Information in the form of maps (Google Maps), as well as other information from the internet, helps tourists to understand the village location and how to get there. However, information about the route and bakpia shops within the village is not available. In general, people with greater familiarity with an environment would produce a more accurate and detailed cognitive map of that environment, and it would have a higher resemblance to a real plan (Evans and Pezder 1980).

Besides, information is also obtained on-the-spot, when the tourists are around the village. This is related to the decision making by tourists that the map is something that helps tourists when they are searching for a location, or when they are lost. Asking local people is an option when there is no local map or when GPS can not be used. Also, the use of GPS helps travelers to know the directions of north, east, south, and west in a particular location.

Physical elements in Village Sanggrahan is a determinant of tourists wayfinding, both in finding the location of Sanggrahan Village or in finding the place of bakpia shops within the 
village. According to Lynch (1985), wayfinding to illustrate how individuals navigate the city uses five spatial images of the town, namely: paths, nodes, districts, edges, and landmarks.

This study shows that only four of the theory is used mainly for areas with information deficits; namely: paths, nodes, edges, and landmarks; while for the district it is not taken into consideration, but the respondents understand it as a positioning tool that they are still in the village of Sanggrahan/Village Bakpia Pathuk by their goals. Respondents tend to mark Pathuk Area with Gate of Bakpia Industrial Centre, and Village Sanggrahan with village gate. In support of Kevin Lynch's theory, the findings show that both gates and buildings around the village are landmarks, which serve as a marker or monument. Inside the village, the open spaces (nodes) are something used by the tourists to mark the direction on the arrival and return routes. Meanwhile, the edges in the village are the dividing walls that form a corridor into the village area; this wall has the potential in the formation of village character that can affect the tourist's experience. On the other hand, districts are not found from the cognitive map described by the respondents because the village is considered as having a weak character.

\section{CONCLUSION}

Initial information from the internet to find the location of the village, as well as the physical elements used as a guide to finding the Pathuk are essential things for the tourists.

As the primary access to Village Sanggrahan village, tourists tend to go through streets that have more excellent connectivity, both from other tourist attractions and homes. Meanwhile, to determine the route to the village, the main gate has a significant role as signage. Respondents tend to go through the path with an entrance gate.

In marking the wayfinding position within the village, Respondents tend to remember some essential things on the journey route inside the village, including open areas (nodes), edges, and buildings (landmarks). Buildings that have a high value as a guide are the ones that are large and close to the entrance, open area, and intersection. Although the signboards are shop boards in the village, they are enough to be remembered by tourists to find the bakpia shops. Meanwhile, in the village, the lack of signage, caused the tourists to make other spatial elements as a benchmark, although such spatial details are weak in their characters.

In the tourism area where information is a deficit, the physical elements of the environment that served as the area's paths, nodes, edges, and landmarks have the potential to shape the character of the city, and this is the case in Village Sanggrahan. In conclusion, based on the research findings, the design and arrangement of the building facade, signage, dividing walls, and open areas served as an essential environmental cue for visitors for their wayfinding. The improvement of specific theme design for these physical elements will create a better characteristic of Sanggrahan village.

\section{REFERENCES}

Apelt, Ron, Crawford, dan David. J. Hogan. 2018. Wayfinding Design Guidelines.

Cashdan, E, K. L Kramer, H Davis, L E., Padilla, dan R. D Greaves. 2016. "Mobility and navigation among the Yucatec Maya." Human Nature 27 (1): 35-50.

Chia, R, dan R Holt. n.d. (2009). Strategy Without Design: The Silent Efficacy of Indirect Action, Cambridge. UK: Cambridge University Press.

Ching, Francis D. K. 2014. Arsitektur: Bentuk, Ruang, dan Tatanan. Jakarta: Penerbit Erlangga.

Downs, Roger M, dan David Stea. 1973. Image and Environment: Cognitive Mapping and Spatial Behavior. London: 
Aldine Transaction.

Evans, G.W, dan K Pezder. 1980. "Cognitive Mapping: Knowledge of Real-World Distance and Location Information." Journal of Experimental Psychology: Human Learning and Memory 6 (1): 13-24.

Kaplan, S, dan R Kaplan. 1982. Cognition and Environment. New York: Praeger.

Kikon, Dolly, dan Bengt Karlsson. 2019. Wayfinding. https://doi.org/10.1017/9781108637817.002.

Kuliga, S. F., B. Nelligan, R. C. Dalton, S. Marchette, A. L. Shelton, L. Carlson, dan C Hölscher. 2019. "Exploring Individual Differences and BuildingComplexity in Wayfinding: The Case of the Seattle Central Library." Environment and Behavior 51 (5): 622-665.

Lynch, Kevin. 1985. The Image of the City. Inggris: The M.I.T. Press.

Passini, Romedi. 1984. Wayfinding in Architecture, Environmental Design Series Volume 4.1984. 54 ed. New York: Van Nostrand Reinhold Company.

Phillips, J., Walford, N., Hockey, A., Foreman, N., \& Lewis, M. (2013). Older people and outdoor environments:

Pedestrian anxieties and barriers in the use of familiar and unfamiliar spaces. Geoforum, 47, 113-124.

Piccardi, L, M Risetti, dan R \& Nori. 2011. "Familiarity and Environmental Representations of a City: a Self-Report Study." Psychological reports 109 (1): 309-26.

Sunaryo, Bambang. 2013. Kebijakan Pembangunan Destinasi Pariwisata: Konsep dan Aplikasinya di Indonesia. Yogyakarta: Gava Media.

Tsoukas, H. 2010. Practice, Strategy-Making and Intentionality: a Heideggerian Onto-Epistemology for Strategy as Practice. Diedit oleh D. Seidl \& E. Vaara (Eds.) Golsorkhi, L. Rouleau. Cambridge. Cambridge, UK: CambridgeUniversity Press.

Turano, K. A., B. Munoz, S. E. Hassan, D. D. Duncan, E. W. Gower, K. B. Roche, dan S. K. West. 2009. "Poor Sense of Direction is Associated with Constricted Driving Space in Older Drivers." Journals of Gerontology: Series B 64 (3): $348-55$. 